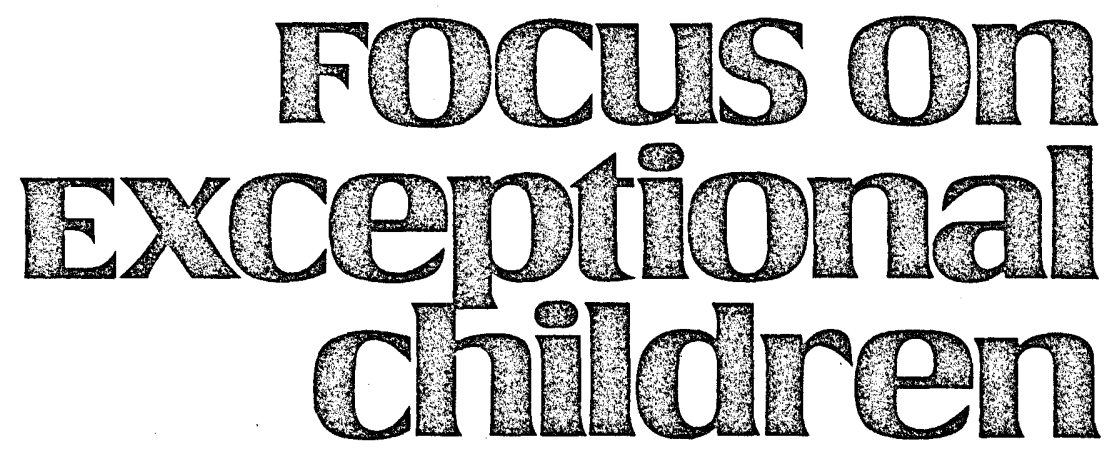

\title{
Measuring Teacher Effectiveness From the Teacher's Point of View
}

\author{
Carol Sue Englert
}

The teacher effectiveness literature has confirmed the strong relationship between specific teacher variables and student achievement within several domains of teacher behavior. These domains include teaching functions related to: (a) classroom management (Brophy, 1983; Emmer, Evertson, \& Anderson, 1980; Evertson \& Emmer, 1982); (b) instructional organization (Berliner \& Rosenshine, 1977; Borg, 1980; Brophy, 1979; Rosenshine, 1980); and (c) lesson presentation (Becker \& Carnine, 1980; Englert, 1984; Rosenshine, 1983; Stevens \& Rosenshine, 1981).

Nonetheless, the documented occurrence of aptitude-by-treatment interactions and the existence of curvilinear relationships indicate that teacher behaviors must be appropriately matched to pupil characteristics if they are to have their intended effects (Brophy, 1979). Although certain teaching strategies work effectively in some contexts, they are irrelevant to others given a different population of learners. This is especially true in special education settings since special education students learn at different rates, and presumably under different instructional conditions.

The less than predictable relationship between specific levels of teacher behavior and pupil outcomes confirms that teachers remain the primary decision makers who must assess pupil characteristics continually and then select teaching methods on the basis of that evaluation. To be effective, teachers must learn to ask questions about their own teaching practices in order to self-monitor and self-regulate their own behavior (Corno \& Mandinach, 1983).

In addition, as a result of reports such as "A Nation at Risk"(National Commission on Excellence in Education, 1983), questions have been raised about the quality of education students receive, and increasing pressure is being placed on educational agencies to provide documentation of teacher and school effectiveness in terms of measurable student progress. Thus, dissemination of recent classroom findings from the teacher effectiveness literature is necessary, but the information must be presented in a decision-making format that enables teachers to examine these concepts in relation to their own unique setting and student populations (Good, 1983).

Dr. Englert is an Assistant Professor, Department of Counseling, Educational Psychology and Special Education, Michigan State University.

๑) Love Publishing Company, 1984. 
This article focuses on the interpretation of classroom research conducted in regular and special education classrooms within the three teaching domains of classroom management, instructional organization, and teaching presentation. Each of these teaching domains is discussed relative to the identification of effective practices of successful teachers. Recommendations for methodology that allow teachers to self-examine and self-evaluate their own teaching practices in each domain also are provided.

\section{CLASSROOM MANAGEMENT}

An important teaching function related to student achievement is to establish a classroom environment conducive to student learning and student attention to academic tasks (Brophy, 1979; Emmer, Evertson, \&

\section{Focus on Exceptional children}

FOCUS ON EXCEPTIONAL CHILDREN (ISSN0015-5IIX) (USPS 203-360) is published monthly except June, July, and August as a service to teachers, special educators, curriculum specialists, administrators, and those concerned with the special education of exceptional children. This journal is abstracted and indexed in Exceptional Child Education Resources, and is also available in microform from Xerox University Microfilm, Ann Arbor, Michigan. Subscription rates, \$18.00 per year. Copyright $\odot$ 1984, Love Publishing Company. All rights reserved. Reproduction in whole or part without written permission is prohibited. Printed in the United States of America. Second class postage is paid at Denver, Colorado.

POSTMASTER: Send address changes to:

Love Publishing Company

Executive and Editorial Office

1777 South Bellaire Street

Denver, Colorado 80222

Telephone (303) 757-2579

\section{EDITORIAL BOARD}

Edward L. Meyen

University of Kansas

Richard J. Whelan

University of Kansas Medical Center

Stanley F. Love Publisher
Carolyn Acheson Senior Editor
Anderson, 1980; Evertson \& Emmer, 1982). Good classroom management maximizes the time students spend on learning tasks and, hence, results in greater student achievement (Brophy \& Evertson, 1977).

In special education, classroom management principles are premised on the assumption that teachers should teach appropriate social behaviors by establishing behavioral expectations in the form of behavioral rules, planning a signal system to elicit these behaviors, and consequating appropriate and inappropriate behaviors in the presence of specific antecedent stimuli (Kerr \& Nelson, 1983). Only recently, however, have these teacher behaviors been validated in the classroom literature and we have come to understand what behaviors and characteristics teachers exhibit in establishing and maintaining a viable classroom management system.

Several studies confirm that the first few weeks of school are critical to the establishment of workable rules and routines that serve as a useful guide for student behavior the remainder of the school year (Emmer et al., 1980). Effective managers do not take prior school learning for granted but view cooperative and "going to school" behaviors as a set of skills that must be directly taught (Anderson, Evertson, \& Emmer, 1980).

Effective managers of student behavior, for example, do not assume that students come to school knowing how to copy from the blackboard, how to line up, how to get the teacher's attention, or how to use the learning center (Anderson et al., 1980). Each of these behaviors is carefully reviewed and taught, including when and how these behaviors are to take place (Emmer, 1981). Even with older students, effective managers take time to review their behavioral expectations at the beginning of the year (Evertson \& Emmer, 1982).

\section{Teaching Rules and Procedures}

In the well-managed classroom, effective teachers actually use semi-formal lessons to actively instruct students in their rules and routines, just as other academic behaviors are taught (Brophy, 1983). Rules are explained, posted, discussed, and a rationale for each rule is provided (e.g., "If everyone talked at once, we wouldn't be able to hear each other speak"). Routines and procedures that occur throughout the day, procedures that are associated with a particular task or lesson (e.g., lining up, movement about room, talk among students, equipment use, small group procedures), are introduced 
gradually as needed (Brohpy, 1983; Emmer, Evertson, Sanford, Clements, \& Worsham, 1984). For example, the occasion of calling the reading group for its first meeting would signal the teacher to teach the routine for "reading group," including what students are to come to group, when they are to come, what props they are to bring, where props are to be placed, how and where students should sit, what behaviors are expected during the lesson, and what to do when the lesson is finished.

Effective managers also differ from their less effective counterparts in the degree to which they provide rule modeling, rule rehearsal, and feedback (Anderson et al., 1980, Emmer et al., 1980, 1984). With respect to rule modeling, effective managers go beyond simply communicating their rules and expectations. They actually demonstrate or model the dimensions of the discrimination to be learned: between sitting correctly and sitting incorrectly, between talking softly and talking loudly, between lining up quickly and lining up too slowly (Anderson et al., 1980).

Rule rehearsal follows demonstration (Arlin, 1979; Emmer et al., 1980, 1984). Effective teachers require students to practice the appropriate behavior in response to a given teacher signal. One student might be called upon to model the behavior, and then the entire class might be asked to execute the procedure upon delivery of the appropriate signal.

Finally, effective teachers carefully monitor student behavior during rule rehearsal and provide feedback specific to the rule (Anderson et al., 1980). This feedback can take one of two forms depending upon students' success in demonstrating the expected behavior. For acceptable student performance teachers use focused praise to reiterate the salient features of the rule that have been followed (e.g., "I see that you remembered the rule for using the learning center. Only two at one time and no talking. Good job.").

When students do not successfully demonstrate the desired appropriate behavior at expected criterion levels, effective teachers stop students immediately, give specific feedback, then present the signal again and require students to practice the appropriate behavior until they perform at criterion levels (Arlin, 1979; Brophy \& Evertson, 1977). In this manner, effective teachers actually drill students on the expected behavior until they perform the new procedure automatically (Arlin, 1979).

\section{Key Management Behaviors}

The discussion of classroom management would be incomplete without attention to two other key behaviors that underlie teachers' management success. These are the "enabling behaviors," or tool skills, which allow teachers to monitor and maintain their classroom management system.

\section{Withitness}

According to Kounin (1970), effective teachers of regular and special education students demonstrate a trait known as "withitness"- the ability to monitor the entire class continuously while directing the learning activities of a subset of the classroom members. Rather than get bogged down with a single child or group during instruction, successful teachers maintain an effective surveillance system. They position themselves carefully and attend to several aspects of the classroom simultaneously through a process of continually scanning and making eye contact with all students outside the lesson (Emmer et al., 1980; Englert \& Thomas, 1982).

\section{Overlappingness}

The research of Kounin and others (Brophy, 1979; Emmer et al., 1980) has confirmed the existence of another trait known as "overlappingness" that also contributes to the effective manager's success. Overlappingness is the teacher's ability not only to attend to two events simultaneously, but also to actually direct and respond to students outside the context of the ongoing lesson.

For example, when students engage in task-relevant behaviors, effective managers consequate these behaviors with praise. When students are not appropriately engaged in task-relevant behaviors, effective managers use nonverbal attention signals to cut short students' inattention and redirect them to the academic task. In this way, effective teachers hold seatwork students accountable for their behavior without even interrupting the flow of the ongoing lesson (Brophy, 1979; Englert \& Thomas, 1982).

Taken together, the research on classroom management indicates the presence of several factors contributing to teachers' management effectiveness. Effective managers provide an orientation period the first few weeks of school, focusing on teaching students the classroom rules and procedures (Emmer et al., 1980). Careful consideration is given to the physical arrangement of the room, traffic patterns, and rules and procedures that will minimize bottlenecks and intrusions into instructional 
time (Brophy, 1983). In addition, effective managers follow up on their expectations throughout the year by reminding students of procedures before they are to carry them out, scheduling additional instruction and practice when needed, monitoring student performance (withitness), and consistently applying consequences (overlappingness) for rule compliance and noncompliance (Brophy, 1983; Evertson \& Emmer, 1982).

\section{Measuring Classroom Management Effectiveness}

In measuring teachers' effectiveness in managing classroom behavior, two general classes of measurement systems can be utilized. The first measurement system involves self-study through a rating instrument that requires the teacher to rate himself/herself on the specific classroom management variables of concern. A rating scale designed for this purpose is shown in Table 1. In using this scale, teachers can identify areas of concern and plan changes in their teaching practices to improve their management effectiveness.

The evaluation of one's teaching performance, however, should be examined continually in relation to observable changes in student performance and achievement as a result of instruction. This leads to the second, and more important class of observation systemsobservation systems that measure student behavior.

A simple classroom management measurement scheme involves collecting pupil data in terms of the number of appropriate or inappropriate behaviors that occur during a specified observation period. This can indicate the teacher's success in teaching, monitoring, and maintaining the classroom rules and procedures. Teachers simply record the occurrences of a targeted behavior using an interval, frequency, rate, or duration recording scheme (Alberto \& Troutman, 1982). If behavior occurs at unacceptable levels, teachers should implement a teaching procedure designed to change student performance in the desired direction, and evaluate the effects of the program on the basis of daily samples of student behavior.

In addition, since a primary objective of effective classroom management is to maintain student attention to academic tasks, measures of pupil task involvement levels can provide a general index of management effectiveness. A system useful for measuring task involvement levels has been described by Englert and Thomas (1982). According to this system, a measure of student task involvement is collected every 10 to 15 minutes on the students engaged in seatwork activities. At the end of the specified interval, the teacher simply looks at each student in the classroom and makes a decision about whether the student is on task (+) or off task (-).

Task involvement data can be recorded for individuals or for an entire classroom. If recorded for individual students, teachers list the names of target students in rows across a recording form and record on task/off task behavior of each student at the end of the interval. An individual student's task involvement for a period is the number of on task intervals divided by the sum of the number of intervals on task and off task.

If task involvement levels are recorded for an entire classroom, teachers simply count the number of students on task and off task during each interval and record these two numbers on an observation form. At the conclusion of the observation period, the class' task involvement level is calculated by dividing the total number of students on task across all intervals by the sum of the number of students on task and off task.

In evaluating one's performance, teachers should keep in mind that a satisfactory task involvement criterion for students engaged in seatwork is $80 \%$ (Borg, 1980; Morsink, 1984); for students in teacher-led activities, a satisfactory task involvement level is $90 \%$ (Emmer et al., 1984). Whenever class task involvement falls consistently below these levels, teachers should examine their management practices in terms of implementation of identified effective practices, enabling them to systematically change their performance in identified areas. The continued collection of daily measures of student task involvement and the establishment of criterion levels of task involvement can assist teachers in evaluating the effects of the management program.

\section{INSTRUCTIONAL ORGANIZATION}

Instructional organization is a second teaching domain that affects student learning. Within the domain of instructional organization, important teacher behaviors include those that maximize learning time, sustain a high level of academic responding or practice, and keep students engaged in the academic task. In sum, research supports the notion that when teachers allocate a great deal of time for instruction while maintaining a high level of task engagement, student learning increases (Rosenshine, 1977). 


\section{TABLE 1 \\ Self Rating Scale for Classroom Management}

Respond to each item in terms of the extent to which it describes yourself:
(1) Not at all descriptive
(4) Descriptive to a large extent
(2) Descriptive to a small extent
(3) Descriptive to a moderate extent
(5) Descriptive to an extremely large extent

\section{Competencies}

Performance

Classroom Set-up and Organization

Evaluation

Arranges physical space and instructional materials to minimize disruptive move-
ment around classroom and to facilitate easy access to high-use materials.

1.2 Establishes and implements minimally disruptive traffic patterns and procedures.

1.3 Establishes and implements procedures for nonacademic class business (e.g., tardiness, material use, movement in and out of room, distributing materials, talk among students, bathroom breaks).

1.4 Establishes and implements procedures for academic business (e.g., seatwork procedures, obtaining help, volunteer behavior during small group, learning centers, set-up and take-down of lessons).

Teaching Rules and Procedures

2.1 Communicates clearly what behavior will be tolerated and what will not.

2.2 Gives behavior reminders and statements of desired behavior in advance of activity.

2.3 Clearly introduces rules, procedures, and consequences at beginning of school year and whenever needed.

2.4 States rules, posts rules, and provides discussion of rules at the time of their introduction.

2.5 Presents examples and non-examples of rules and procedures.

2.6 Requires student rehearsal of rules and procedures.

2.7 Monitors rule compliance and provides specific behavioral feedback during

2.8 Consequates rule noncompliance by stopping inappropriate behavior immediately and requiring students to practice the procedure until it is performed automatically.

\section{Maintaining Rules and Procedures}

3.1 Positions self in the room to provide high degree of visibility (e.g., can make eye contact with all students).

3.2 Scans constantly and makes eye contact with all students on an equal basis.

3.3 Detects disruptive behavior early and cites rule or procedure in responding to disruptive behavior.

3.4 Reinforces appropriate performance through specific praise statements (e.g., states specific behaviors).

3.5 Administers praise contingently.

3.6 Includes students in the management of their own behavior.

3.7 Uses nonverbal signals to direct students when teaching other groups of students.

$\begin{array}{lllll}1 & 2 & 3 & 4 & 5 \\ 1 & 2 & 3 & 4 & 5 \\ 1 & 2 & 3 & 4 & 5 \\ 1 & 2 & 3 & 4 & 5\end{array}$

$\begin{array}{lllll}1 & 2 & 3 & 4 & 5\end{array}$

$\begin{array}{lllll}1 & 2 & 3 & 4 & 5\end{array}$

$\begin{array}{lllll}1 & 2 & 3 & 4 & 5\end{array}$

$\begin{array}{lllll}1 & 2 & 3 & 4 & 5\end{array}$

$\begin{array}{lllll}1 & 2 & 3 & 4 & 5\end{array}$

12345

$\begin{array}{lllll}1 & 2 & 3 & 4 & 5\end{array}$

$\begin{array}{lllll}1 & 2 & 3 & 4 & 5\end{array}$ $\begin{array}{lllll}1 & 2 & 3 & 4 & 5\end{array}$

$\begin{array}{lllll}1 & 2 & 3 & 4 & 5\end{array}$

12345

$\begin{array}{lllll}1 & 2 & 3 & 4 & 5\end{array}$

$\begin{array}{lllll}1 & 2 & 3 & 4 & 5\end{array}$

$\begin{array}{lllll}1 & 2 & 3 & 4 & 5\end{array}$

$\begin{array}{lllll}1 & 2 & 3 & 4 & 5\end{array}$ 


\section{Allocated Time}

Allocated time is the amount of time scheduled for an academic subject. Allocated time can be measured simply by examining teachers' schedule books or by observing teachers and calculating the number of minutes in direct instruction allowed a particular student or group. Presumably, achievement increases as teachers allocate more time for instructional activities (Borg, 1980; Greenwood, Delquadri, Stanley, Sasso, Whorton, \& Schulte, 1981). Leinhardt, Zigmond, and Cooley (1981), for example, have suggested that an additional 5 minutes per day in silent reading by learning disabled students would improve performance on an end-of-year achievement measure by 1 month.

Although a major portion of the school day is assumed to be spent in instructional activities, this is not always the case. Rosenshine (1980) and Good (1983) have reported that up to $50 \%$ of the school day in regular classrooms may be spent in noninstructional activities. Similar time allocations have been reported in special education classrooms (Thurlow, Ysseldyke, Graden, \& Algozzine, 1983).

Academic response opportunities during time allocated for instruction may occur at even lower levels. Thurlow et al. (1983), for example, reported that some learning disabled students averaged only 9 minutes per day in active reading practice, and only one-fourth of the 1.5 hours allocated for reading instruction involved active or overt academic responding (e.g., reading, writing, speaking). Similarly, Fox (1974) found that some inner city students averaged only 20 seconds per day in active reading practice.

Based on classroom observations similar to these, Greenwood et al. (1981) have suggested that academic practice and opportunity to respond are concepts that regular or special education teachers do not always understand or practice. Yet, if teachers are to diminish the gap between special education students and their normally achieving peers, they must maximize the opportunities for students to make active academic responses during both direct instruction and seatwork activities (Greenwood et al., 1981).

Three organizational techniques can augment the time allocated for instruction and the opportunity for academic practice: (a) lesson scheduling and management, (b) small-group instruction, and (c) tutoring systems.

\section{Lesson Scheduling and Management}

Investigations indicate that careful attention to scheduling can increase the time available for instruction (Rosenshine, 1980). A primary tactic special education teachers can use is to schedule generous amounts of time for instruction while decreasing the time spent in noninstructional activities, such as task management, socializing, and waiting for teacher assistance (Leinhardt et al., 1981).

Adherence to lesson schedules also can increase the time available. When teachers fail to start and stop lessons on time, or when lessons are inconsistently scheduled or "bumped" by other activities, individual students lose valuable instructional time. Lesson schedules are further intruded upon when students do not move briskly through the change of lesson or activity in the transition times between lessons. According to Engelmann(1982a), teachers can help students make a brisk transition by: (a) modeling transition behaviors, (b) signaling the onset and termination of the transition, (c) correcting errors of slowness or disruptiveness, (d) testing on correct performance and repeating until firm, and (e) reinforcing quick and quiet transitions.

Likewise, effective managers insulate themselves and their students from intrusions into academic time by establishing rules for working students (e.g., rules for early finishers, stalled students), and by teaching and rehearsing all new lesson procedures and equipment in advance. Given these rules and rehearsal, students are continually cued what to do next (Good, 1983), and time normally wasted as a result of student questions is redirected to purposeful academic activities (Brophy, 1979)

\section{Small-Group Instruction}

In addition to careful scheduling, research suggests that the time spent working with a number of students is positively correlated to achievement gains, whereas the time spent working with one or two students is negatively related to achievement gains (Rosenshine, 1980; Soar, 1973; Stallings \& Kaskowitz, 1974). A primary means by which teachers can interact with a large number of students per hour is by grouping students for instruction.

For example, a special education teacher with 12 students could teach only 6 students per hour, or $50 \%$ of the 
classroom population, if students were taught in one-onone arrangements in 10-minute lessons. In contrast, if students were grouped for instruction into small groups of 3 students, $100 \%$ of the students could be accommodated for instruction in 15-minute lessons (Stevens \& Rosenshine, 1980). In terms of the time students spend in seatwork, the first classroom situation means that 6 students work alone for an entire hour without instruction from the teacher; in the second situation, no student is left working alone without instruction or feedback.

\section{Tutoring Systems}

Teachers can use a third means to increase the time allocated for instruction. Hall, Delquadri, Greenwood, and Thurston (1982) have recommended the use of tutoring systems to increase instructional time and to provide students with greater opportunities to make active academic responses. Because tutors in these programs are agents other than teachers (parents, volunteers, peers), tutors can increase academic learning time without increasing the instructional demands placed on teachers or lessons.

Tutoring systems have been successfully used to develop sight word vocabulary (Hall et al., 1982; Heron, Heward, Cooke, \& Hill, 1983), reading fluency (Meisgeier \& Menius, 1980), spelling skills (Delquadri, Greenwood, Stretton, \& Hall, 1983), and math skills (Hall et al., 1982; Harris \& Sherman, 1973). The advantage of tutoring systems over other forms of independent study is dramatically illustrated by Delquadri et al. (1983), who reported that spelling peer tutors increased average weekly practice from once per week for 6 of 18 spelling words to 10 practices per week for all 18 spelling words. Moreover, the authors noted a dramatic improvement in the spelling achievement of special education students, whereas their normally achieving peers made lesser gains.

Successful tutoring programs such as the one described by Delquadri et al. are characterized by a strong tutor training component and frequent measurement of student progress. When these elements are integrated into the tutoring system, tutoring programs can augment direct instruction time and increase student achievement while replacing inefficient practice with more active forms of academic practice and responding.

\section{Engaged Time}

Although emphasis has been placed on time in instruc- tion, the time should not be increased without consideration being given to students' task engagement. For example, a teacher might increase the lesson session time from 25 to 50 minutes, but if the pupil is on taks only $50 \%$ of the time, the student is still receiving only 25 minutes of instruction. Because of the importance of task engagement to student achievement (Good \& Beckerman, 1978), teachers must not only allocate time for instruction, but they must also find ways to put students in contact with the curriculum, and keep them engaged.

Task engagement can be measured in two situations: (a) direct instruction situations involving teacherdirected lessons, and (b) seatwork situations in which students work alone. Typically, researchers suggest that attention during teacher-directed lessons remains high, whereas attention during seatwork occurs at lower levels because of the diminished number of teacher-student interactions (Rosenshine, 1980).

The problem is further compounded in that seatwork activities often consume a great deal of instructional time (up to $50 \%$ and $70 \%$ of the school day). Therefore, a major concern of effective teachers is the proper management of seatwork activities to maintain high task engagement and to promote academic learning (Rosenshine, 1980; Stevens \& Rosenshine, 1981). Three management techniques can facilitate the performance of seatwork students: monitoring seatwork, fostering accuracy on seatwork tasks, and holding students accountable.

\section{Monitoring Seatwork}

Several studies suggest that regular and special education students do not remain engaged in seatwork tasks unless supervised and monitored by an adult (Berliner \& Rosenshine, 1977; Englert \& Thomas, 1982). In addition to continually scanning the classroom and monitoring task involvement, successful managers of seatwork maintain high mobility and circulate frequently during transition times to assist seatwork students who have questions and to monitor academic progress Englert \& Thomas, 1982). These frequent, substantive interactions with students during seatwork give teachers the occasion to provide immediate assistance and continual feedback to students, thereby increasing student attention to task and increasing student achievement (Rosenshine, 1980).

\section{High Accuracy}

Accuracy on seatwork tasks has been found to be an important factor contributing to student learning 
(Evertson \& Emmer, 1982). Several investigations indicate that low-achieving students need to work at high levels of accuracy in order to receive the full benefit of the seatwork practice. In summarizing the results of this body of research, Rosenshine (1983) has suggested that seatwork practice should occur at success levels above $90 \%$ accuracy.

Additionally, teachers should consider that a primary purpose of seatwork is to provide drill and overlearning in order to consolidate and develop automaticity on previously taught skills rather than be used to teach new skills or to provide practice on tangential skills (Brophy, 1983). Appropriate seatwork activities are those that allow students to directly practice the academic behavior (Hall et al., 1982). In reading, this means tasks in which students read orally or silently. In spelling, appropriate spelling tasks are those requiring the student to write words from memory or to dictation rather than copy words in a spelling workbook. When used in this manner, seatwork is not busywork but provides further academic practice on a targeted skill.

\section{Accountability}

Teachers must hold students accountable for their assignments and seatwork tasks. According to Evertson and Emmer (1982), more effective teachers keep track of student progress and work completed and require students to complete their work on time, according to specific work standards regarding format, neatness, and accuracy. When work is incomplete, effective teachers require students to redo assignments until they meet acceptable performance criteria (Anderson et al., 1980; Evertson \& Emmer, 1982).

Similarly, Anderson's (1984) study revealed that many teachers of low-achieving students did not make reference to what was being practiced and how it was related to other learning. As a result, seatwork practice occurred without students knowing what they were supposed to master or what was expected. Under this type of circumstances, students completed seatwork "to get finished" rather than to develop mastery of their own learning. Knowledge of the criterion task and goal has a critical effect on the amount special education students learn (Wong, Wong, \& LeMare, 1982), so effective teachers inform students of the rationale and objectives when assignments are made.

\section{Measuring Instructional Organization Effectiveness}

To measure one's effectiveness in the domain of instructional organization, a rating instrument can be used to self-evaluate and identify areas of concern. For this purpose, a rating scale is provided in Table 2.

To obtain more specific measures of instructional organization, other quantitative measures can be utilized. Allocated time can be measured simply by examining teachers' daily lesson schedules. In doing so, teachers should consider whether they have allocated sufficient time for instruction, especially to the lessons of students who lag the farthest behind expected achievement levels.

Teachers also should compare daily planned schedules against actual observable times that lessons are started and stopped. Discrepancies between planned and actual lesson schedules can help teachers determine whether they are adhering to lesson schedules to maximize instructional opportunities for all students. Also, this information can indicate whether instructional time is being lost because of inefficient transitions.

For more specific data on transitions, teachers can measure transition time by using a stopwatch to record the time elapsed between delivery of the transition signal and students' completion of the transition behaviors. Engelmann (1982b) has suggested that a brisk transition involving a change in place and activity can be completed in 2 minutes; a transition involving only a change in activity can be completed in 30 seconds.

\section{Measuring Direct Instruction Activities}

In accordance with the recommendation that teachers should interact with as many students as possible in direct instruction activities, teachers should examine the proportion of students they involve in direct instruction opportunities per hour. To measure this, teachers can count the number of different students in teacherdirected lessons in a 1-hour period and divide this number by the total number of students in the classroom during that time. A minimum percentage of students that should be involved in direct instruction is $70 \%$, although lower levels may result if students are not able to be grouped for instruction. As much as possible, teachers should manipulate their scheduling of groups and lessons to break up seatwork and increase the percentage of students involved in instruction. 


\section{TABLE 2 \\ Instructional Organization}

\section{Competencies}

\section{Performance \\ Evaluation}

\section{Allocated Time}

1.1 Maximizes time in instruction by continually scheduling students in direct instruction (e.g., interacts with $70 \%$ or more of the students per hour).

1.2 Minimizes time in non-instructional activities (e.g., spends $80 \%$ or more of class time in instructional activities).

1.3 Keeps transition time between lessons short (e.g., no more than 3 minutes between change of students and activity; no more than 30 seconds when a change of activity only).

1.4 Establishes procedures for lessons that signal a clear beginning and end.

1.5 Gains all students' attention at the beginning of the lesson and maintains student attention during lesson at $90 \%$ level.

1.6 Prepares students for transitions in advance by stating behavioral expectations and informing students that lesson is drawing to a close.

$\begin{array}{lllll}1 & 2 & 3 & 4 & 5 \\ 1 & 2 & 3 & 4 & 5 \\ 1 & 2 & 3 & 4 & 5 \\ 1 & 2 & 3 & 4 & 5 \\ 1 & 2 & 3 & 4 & 5 \\ 1 & 2 & 3 & 4 & 5\end{array}$

\section{Engaged Time}

2.1 Maintains students' attention during seatwork at $80 \%$ levels or higher.

2.2 Monitors seatwork students continuously through eye scanning.

2.3 Circulates among seatwork students between lessons to assist students and to monitor progress.

2.4 Maintains seatwork accuracy at $90 \%$ level or higher.

2.5 Tells rationale for seatwork and communicates the importance of the assignment.

2.6 Provides active forms of seatwork practice clearly related to academic goals.

2.7 Sets seatwork and assignment standards (neatness, accuracy, due dates).

2.8 Uses tutoring (e.g., peer, volunteers, aides) and other specialized instructional technology to increase opportunity for active academic responding during seatwork.

2.9 Establishes procedures for early finishers, students who are stalled, and those seeking help.

2.10 Schedules time to review seatwork.

2.11 Requires that students correct work and make up missed or unfinished work.

2.12 Gives informative feedback to students in making written or verbal corrections.

$\begin{array}{lllll}1 & 2 & 3 & 4 & 5\end{array}$

$\begin{array}{lllll}1 & 2 & 3 & 4 & 5\end{array}$

$\begin{array}{lllll}1 & 2 & 3 & 4 & 5\end{array}$

$\begin{array}{lllll}1 & 2 & 3 & 4 & 5\end{array}$

$\begin{array}{lllll}1 & 2 & 3 & 4 & 5\end{array}$

$\begin{array}{lllll}1 & 2 & 3 & 4 & 5\end{array}$

$\begin{array}{lllll}1 & 2 & 3 & 4 & 5\end{array}$

$\begin{array}{lllll}1 & 2 & 3 & 4 & 5\end{array}$

$\begin{array}{lllll}1 & 2 & 3 & 4 & 5\end{array}$

$\begin{array}{lllll}1 & 2 & 3 & 4 & 5\end{array}$

$\begin{array}{lllll}1 & 2 & 3 & 4 & 5\end{array}$

$\begin{array}{lllll}1 & 2 & 3 & 4 & 5\end{array}$

\section{Measuring Seatwork Activities}

Seatwork activities comprise another aspect of instruction that teachers have to consider. Seatwork accuracy, for example, has been found to be an important factor contributing to student achievement. To monitor this, teachers can graph individual students' percent accuracy on specific seatwork assignments. When performance consistently falls below $90 \%$, teachers should reexamine seatwork tasks to determine whether they are of suitable difficulty and whether they provide additional practice opportunities on a previously taught academic skill.

Teachers also must consider whether they have provided sufficient instructional assists, modeling, and directions prior to assigning the seatwork tasks. If teachers identify this as a problem area, they should 
collect baseline data, implement an intervention program, and evaluate the program's success on the basis of student change. Involving the pupils themselves in charting and measuring their seatwork accuracy can further increase students' seatwork performance, as well as their accountability in maintaining high performance levels.

\section{LESSON PRESENTATION}

Presentation of subject matter in lessons is the third domain in the discussion of teacher effectiveness. According to Rosenshine (1983) and Englert (1984), three major lesson phases signal different teacher behaviors.

\section{First Phase}

In the first lesson phase, teachers have an important role in reviewing the previous day's learning, communicating lesson rules and expectations, and preparing students for the upcoming lesson's activities (Englert, 1984). In the review, effective teachers go beyond simply saying, "Remember what we did yesterday?" They actually test student performance by requiring students to verbalize the meaning of concepts and to apply those concepts to problems. Once the review has been completed, teachers engage in goal-setting behaviors that provide an overview of the lesson, including information concerning what is to be learned, what pupils will be doing, and why it is important (Berliner, 1979).

Since learning is optimal when students have information to relate to the new concept, effective teachers attempt to establish a link between the new information and what students already know (Anderson, 1984; Roehler \& Duffy, 1984). As Roehler and Duffy (1984) have pointed out, teachers who provide explicit information about desired student behaviors and the importance of what is being taught set the occasion for learning to occur. Unfortunately, the tendency of some teachers of low-achieving students is to spend much of the allocated time working on drill without adequate presentation or discussion of purposes related to relevant concepts, so that students are unable to benefit from the new information (Brophy, 1982; Duffy, 1983). With low-achieving students, particularly, teachers have to make frequent reference to what is being learned, why it is important, and how it relates to other learning (Anderson, 1984).

\section{Second Phase}

In the second lesson phase, active demonstration and practice of new concepts are important behaviors that further affect the quality of student learning (Good \& Grouws, 1979; Rosenshine, 1983; Stevens \& Rosenshine, 1981). Teacher behaviors appropriate to this phase include teacher modeling of the concept rule or procedure, focusing attention on relevant dimensions of concept, provision of many examples and nonexamples to illustrate the concept, and controlled practice of the concept through student recitation of each of the component parts of the rule or principle under study (Becker \& Carnine, 1980; Stevens \& Rosenshine, 1981).

In this stage, students actively practice the concept by reciting the concept rule or procedure and saying why particular instances are examples or nonexamples of a concept. Such activities test students' understanding while requiring them to rehearse the concept rule in making decisions. Throughout this early demonstration phase, effective teachers maintain high levels of accurate responding through prompts and cues that focus attention on the relevant features of the concept prior to initiating the target student response (Englert, 1984) (e.g., "Do 'car' and 'automobile' mean the same thing? So are they synonyms?").

Several investigations underscore the importance of modeling prior to initiation of the students' response (Good \& Grouws, 1979; Roehler \& Duffy, 1984). That is, teachers should actively present concepts, explain processes, and demonstrate how one regulates, monitors, and uses a skill to accomplish a goal (Roehler \& Duffy, 1984). A useful format for teaching students new concepts and skills is the model-lead-test format of Direct Instruction programs (Carnine \& Silbert, 1979). In this format the teacher models a procedure or response by verbalizing the steps in the procedure or the correct response aloud. The teacher then leads student performance by using prompts to guide them through a rehearsal of each step. Last, the teacher tests students' mastery of the procedure by having them perform the procedure independently in a test step.

\section{Third Phase}

In the third and final lesson phase, teachers continue to provide students with repeated practice opportunities 
until they are confident and firm in making the learned response (Rosenshine, 1978). Teachers make fewer uses of prompts in this stage, but they do use systematic error correction procedures for drill on all troublesome concepts. When students err, the teacher stays with the student and gives cues or prompts until they give a correct response rather than tell the student the correct answer or call on another student (Brophy, 1979; Stevens \& Rosenshine, 1980). Also, the teacher repeatedly presents items on which students have erred until the student gives correct responses consistently. When students provide correct responses, the teacher acknowledges their performance through appropriate and contingent praise statements (Englert, 1984).

\section{General Teaching Practices}

In addition to the aforementioned lesson phases, three general instructional practices-pacing, practice for accuracy, and mastery learning-are consistently linked to pupil achievement. These direct instruction practices underlie effective programming within each lesson phase.

\section{Pacing}

Research suggests that teachers who maintain a brisk pace and a high rate of progress through the curriculum produce greater academic gains than teachers who do not (Berliner \& Rosenshine, 1977; Brophy, 1979; Carnine, 1981; Englert, 1983, 1984). Teachers must attempt to make better use of time by moving more rapidly through the curriculum: teaching more words per lesson, covering more pages per lesson, asking more questions per lesson, or presenting learning trials more quickly.

\section{Accuracy}

Teacher expertise in providing successful practice at levels of $80 \%$ accuracy or higher during teacher-directed lessons is another factor that positively influences the performance of low-achieving students (Block, 1980; Borg, 1980; Brophy \& Evertson, 1977; Rosenshine, 1983; Stevens \& Rosenshine, 1981). Investigations support the notion that low-achieving and special education students should work on academic tasks for which the error rates are low and the success rates are high during direct instruction (Englert, 1983, 1984; Rosenshine, 1977).

\section{Mastery Learning}

Mastery learning formats can help teachers plan and evaluate the instructional program. In the mastery learning format teachers continually administer progress tests to evaluate students' mastery of prespecified learning outcomes. Remediation for individual students who do not achieve criterion on specific outcomes is scheduled in the form of correctives that include alternative instructional strategies and additional learning time (Guskey, 1980). Once the corrective has been delivered, teachers administer another test to ascertain students' progress on targeted academic objectives. Because of the frequent monitoring of student progress and the individualized way in which instructional time and procedures are scheduled, mastery learning systems can be of great benefit to special education students (Guskey, 1980).

\section{MEASURING LESSON PRESENTATION EFFECTIVENESS}

In measuring one's effectiveness in presenting lessons, a rating scheme can be used to evaluate one's performance. Table 3 gives a checklist for this purpose. Since teachers might have difficulty recalling a lesson in its entirety, listening to a tape recording of the lesson as they complete the rating instrument may be useful.

In addition to the rating scheme, teachers should use student behavior and mastery of targeted academic objectives as the criterion by which they measure their teaching effectiveness. The IEP, for example, can be used to evaluate the teacher's success in moving students through a specific set of targeted objectives according to prespecified timelines. Daily measurement and gráphing of student performance on specific academic skills also can help teachers evaluate the immediate and long-term effects of instruction on student learning. In fact, a growing body of research suggests that direct and frequent (daily) measurement contributes to teachers' effectiveness in making timely and accurate program decisions (Wesson, King, \& Deno, 1984; Haring, Liberty, \& White, 1980).

Student accuracy during lesson presentation has been identified as a critical variable in teachers' effectiveness. To evaluate this area, teachers can tape record a lesson and listen to it. Teachers should record the number of stimuli or questions they present, and the number of stimuli/questions to which students respond correctly or incorrectly. By dividing the number of correct responses 


\title{
TABLE 3 \\ Teaching Presentation
}

\section{Competencies}

\author{
Performance \\ Evaluation
}

\section{Lesson Presentation-Introduction Phase}

1.1 Reviews prior learning by requiring active student recitation or practice of previous day's skills.

1.2 States the objective of the lesson and communicates to students what they will be expected to do to demonstrate mastery of the new skill.

1.3 Provides an overview of the lesson.

1.4 Relates new concepts to old by stating how a new skill is like or different from those the student already knows.

1.5 Activates the student's prior experiences to aid comprehension and understanding.

1.6 Conveys purposefulness for learning by stating the rationale.

$\begin{array}{lllll}1 & 2 & 3 & 4 & 5 \\ 1 & 2 & 3 & 4 & 5 \\ 1 & 2 & 3 & 4 & 5 \\ 1 & 2 & 3 & 4 & 5 \\ 1 & 2 & 3 & 4 & 5 \\ 1 & 2 & 3 & 4 & 5\end{array}$

Demonstration Phase

2.1 Models topography of behavioral response for factual learning, and models steps of a procedure in procedural learning.

2.2 Requires students to rehearse new behaviors and procedures based on imitation of the teacher's model.

2.3 Points out distinctive features of new concepts.

2.4 States concept definition and provides rehearsal.

2.5 Presents many examples and nonexamples of new concepts or generalization and explains why they are examples or nonexamples.

2.6 Provides discrimination activities (e.g., series of examples and nonexamples) to test student performance and understanding.

2.7 Asks students to give rationale or explain decision in determining why particular instances are examples or nonexamples of the concept.

2.8 Delivers specific cues and prompts prior to the initiation of student response, to maintain accuracy above $80 \%$.

2.9 Asks frequent questions to test understanding and provides opportunities for academic practice.

\section{Extended Practice Phase and Evaluation}

3.1 Repeats practice opportunities until students are not making errors.

3.2 Uses error correction procedures (e.g., prompts or models) rather than tell answer or call on another student.

3.3 Provides error drill by repeatedly presenting concepts on which students have erred.

3.4 Follows up on correct responses with contingent and specific praise.

3.5 Maintains a brisk pace during the lesson.

3.6 Provides daily, weekly, and monthly reviews.

3.7 Provides frequent tests to determine students' mastery of academic objectives.

3.8 Reteaches or makes instructional decisions on the basis of students' performance on tests.

3.9 Maintains continuous records and graphs of student progress.

$\begin{array}{lllll}1 & 2 & 3 & 4 & 5\end{array}$

$\begin{array}{lllll}1 & 2 & 3 & 4 & 5\end{array}$

$\begin{array}{lllll}1 & 2 & 3 & 4 & 5\end{array}$

$\begin{array}{lllll}1 & 2 & 3 & 4 & 5\end{array}$

$\begin{array}{lllll}1 & 2 & 3 & 4 & 5\end{array}$

$\begin{array}{lllll}1 & 2 & 3 & 4 & 5\end{array}$

$\begin{array}{lllll}1 & 2 & 3 & 4 & 5\end{array}$

$\begin{array}{lllll}1 & 2 & 3 & 4 & 5\end{array}$

$\begin{array}{lllll}1 & 2 & 3 & 4 & 5\end{array}$ $\begin{array}{lllll}1 & 2 & 3 & 4 & 5\end{array}$

$\begin{array}{lllll}1 & 2 & 3 & 4 & 5\end{array}$

$\begin{array}{lllll}1 & 2 & 3 & 4 & 5\end{array}$

$\begin{array}{lllll}1 & 2 & 3 & 4 & 5\end{array}$

$\begin{array}{lllll}1 & 2 & 3 & 4 & 5\end{array}$

$\begin{array}{lllll}1 & 2 & 3 & 4 & 5\end{array}$

$\begin{array}{lllll}1 & 2 & 3 & 4 & 5\end{array}$

$\begin{array}{lllll}1 & 2 & 3 & 4 & 5\end{array}$

$\begin{array}{lllll}1 & 2 & 3 & 4 & 5\end{array}$ 
by the sum of the correct and incorrect responses, teachers have a measure of the students' percentage of accuracy during the lesson. Criterion goals for acceptable performance should be above $80 \%$ accuracy during teacher-directed lessons.

Teachers also can use the tape of the lesson to evaluate their rate of lesson presentation, or pacing. This can be calculated by dividing the number of teacher questions in an instructional period by the total session time in minutes. Although rate criteria vary according to the subject matter area and instructional arrangements, teachers should strive to maintain a brisk pace. When using scripted materials, such as the Direct Instruction programs, correct rates should average nine-to- 15 trials per minute (Engelmann, 1982b).

As teachers increase their presentation rate, however, they should confirm that students' responses remain at high accuracy levels. When accuracy falls below $80 \%$, teachers should reexamine their instructional program to determine whether they have provided sufficient instructional cues to make learning errorless.

Strategies that can increase correct academic responding include: (a) increasing the amount of teacher modeling and demonstration, (b) preprompts or prequestions that focus attention on the relevant features of the concept, (c) increased student responding, (d) unmixed (single skill) to mixed (multi-skill) practice, (e) cumulative introduction of facts or skills rather than simultaneous presentation, and ( $f$ ) presentation of information in small instructional steps. As these techniques imply, effective teachers modify the way information is presented-rather than modify consequences or reduce the pace of the lesson-to achieve high levels of correct responding.

\section{SUMMARY}

In summary, research studies corroborate that teacher behavior-what teachers say and do in the classroomhas a critical effect on student learning. In special education settings teachers have an important role to play in managing the classroom environment to facilitate development of social and academic behaviors. If handicapped students are to make adequate progress, teachers must manage the classroom environment so that students are engaged in academic tasks that are functionally relevant and provide adequate academic practice. By giving careful attention to classroom management, instructional organization, and lesson presentation, teachers can make a difference and can have a critical impact on student learning.

Observation systems have been suggested as a means by which teachers can evaluate their teaching performance. Observation systems, however, are not a panacea underlying teacher evaluation and improvement. The process of documenting teaching means that teachers must act as researchers in their own classroom by systematically evaluating the effects of instructional decisions on the basis of measurable changes in student performance (Kimball, Heron, \& Weiss, 1984). As Rippey (1983) has suggested, the best measure of good teaching is not what the teacher does-it's what the student does. By combining self-evaluation with measurable outcomes of student performance, teachers will be in a good position to continually evaluate teaching effects, alter instruction to meet individuals' needs, and document teaching effectiveness in relation to their own unique setting and student needs.

\section{REFERENCES}

Alberto, P.A., \& Troutman, A.C. (1982). Applied behavior analysisfor teachers. Columbus, $\mathrm{OH}$ : Charles E. Merrill.

Anderson, L.M. (1984). The environment of instruction: The function of seatwork in a commercially developed curriculum. In G.G. Duffy, L.R. Roehler, \& J. Mason (Eds.), Comprehension instruction: Per spectives and suggestions (pp. 93-103). New York: Longman.

Anderson, L.M., Evertson, C.M., \& Emmer, E.T. (1980). Dimensions in classroom management derived from recent research. Journal of Curriculum Studies, 12, 343-346.

Arlin, M. (1979). Teacher transitions can disrupt time flow in classrooms. American Educational Research Journal, 16, 42-56.

Becker, W.C., \& Carnine, D.W. (1980). Direct instruction: An effective approach to educational intervention with the disadvantaged and low performers. In B.B. Lahey \& A.E. Kazden (Eds.), Advances in clinical child psychology (Vol. 3., pp. 429-473). New York: Plenum Publ.

Berliner, D.C. (1979). Tempus Educare. In P.L. Peterson \& H.J. Walberg (Eds.), Research on teaching: Concepts, findings and implications (pp. 120-135). Berkeley: McCutchan.

Berliner, D.C. (1981). Academic learning time and reading achievement. In J.T. Guthrie (Ed.), Comprehension and teaching: Research views (pp. 203-226). Newark, DE: International Reading Assoc.

Berliner, D.C., \& Rosenshine, B.V. (1977). The acquisition of knowlege in the classroom. In R.C. Anderson, F.J. Spiro, \& W.E. Montague (Eds.), Schooling and the acquisition of knowledge (pp. 375-396). Hillsdale, NJ: Erlbaum.

Block, J.H. (1980). Success rate. In C. Denham \& A. Lieberman (Eds.), Time to learn (pp. 95-106). Washington, DC: National Institute of Education.

Borg, W.R. (1980). Time and school learning. In C. Denham \& A. Lieberman (Eds.), Time to learn (pp. 27-72). Washington, DC: National Institute of Education.

Brophy, J.E. (1979). Teacher behavior and its effects. Journal of Educational Psychology, 71, 733-750. 
Brophy, J.E. (1982). How teachers influence what is taught and learned in classrooms. Elementary School Journal, 83, 1-13.

Brophy, J.E. (1983). Classroom organization and management. Elementary School Journal, 83, 254-285.

Brophy, J.E., \& Evertson, C.M. (1977). Teacher behavior and student learning in second and third grades. In G.D. Borich (Ed.), The appraisal of teaching: Concepts and process (pp. 79-95). Reading, MA: Addison-Wesley.

Carnine, D.W. (1981). High and low implementation of direct instruction teaching techniques. Education \& Treatment of Children, 4 , 43-51.

Carnine, D.W., \& Silbert, J. (1979). Direct instruction reading. Columbus, $\mathrm{OH}$ : Charles E. Merrill.

Corno, L., \& Mandinach, E.B. (1983). The role of cognitive engagement in classroom learning and motivation. Educational Psychologist, 18, 88-108.

Delquadri, J.C., Greenwood, C.R., Stretton, K., \& Hall, R.V. (1983). The peer tutoring spelling game: A classroom procedure for increasing opportunities to respond and spelling performance. Education \& Treatment of Children, 6, 225-239.

Duffy, G.G. (1983). From turn taking to sense making: Broadening the concept of reading teacher effectiveness. Journal of Educational Research, 76, 134-139.

Emmer, E.T. (1981). Effective management in junior high math classes (Report No. 6111). Austin: Texas University, Research and Development Center for Teacher Education.

Emmer, E.T., Evertson, C.M., \& Anderson, L.M. (1980). Effective management at the beginning of the school year. Elementary School Journal, 1980, 80, 219-231.

Emmer, E.T., Evertson, C.M., Sanford, J.P., Clements, B.S., \& Worsham, M.E. (1984). Classroom management for secondary teachers. Englewood Cliffs, NJ: Prentice-Hall.

Engelmann, S. (1982a). Dear Ziggy. Direct Instruction News, I(3), 9.

Engelmann, S. (1982b). Study of 4th-6th grade basal reading series: How much do they teach? Direct Instruction News, 1(3), 5 .

Englert, C.S. (1983). Measuring special education teacher effectiveness, Exceptional Children, 50, 247-254.

Englert, C.S. (1984). Examining effective direct instruction practices in special education settings. Remedial \& Special Education, 5, 38-47.

Englert, C.S., \& Thomas, C.C. (1982). Management of task involvement in special education classrooms. Teacher Education \& Special Education, 5, 3-10.

Evertson, C.M., \& Emmer, E.T. (1982). Effective management at the beginning of the school year in junior high classes. Journal of Educational Psychology, 74, 485-498.

Fox, R.G. (1974). The effects of peer tutoring on oral reading behavior of underachieving fourth grade pupils. Unpublished doctoral dissertation, University of Kansas, Lawrence.

Good, T.L. (1983). Classroom research: A decade of progress. Educational Psychologist, 18, 127-144.

Good, T.L., \& Beckerman, T.M. (1978). Time on task: A naturalistic study in sixth-grade classrooms. Elementary School Journal, 78, 193201 .

Good, T.L., \& Grouws, D. (1979). The Missouri mathematics effectiveness project: An experimental study in fourth-grade classrooms. Journal of Educational Psychology, 71, 355-362.

Greenwood, C.R., Delquadri, J., Stanley, S., Sasso, G., Whorton, D., \& Schulte, D. (1981). Allocating opportunities to respond as a basis for academic remediation: A developing model for teaching. In R.B. Rutherford, A.G. Prieto, \& J.E. McGlothlin (Eds.), Severe behavior disorders of children and youth, monograph in behavior disorders (pp. 22-33). Reston, VA: Council for Children with Behavioral Disorders.

Guskey, T.R. (1980). Individualizing within the group-centered classroom: The mastery learning model. Teacher Education \& Special Education, 3(4), 47-54.

Hall, R.V., Delquadri, J., Greenwood, C.R., \& Thurston, L. (1982).
The importance of opportunity to respond in children's academic success. In E.B. Edgar, N.G. Haring, J.R. Jenkins, \& C.G. Pious (Eds.), Mentally handicapped children: Education and training (pp. 107-140). Baltimore: University Park Press.

Haring, N.G., Liberty, K.A., \& White, O.R. (1980). Rules for databased strategy decisions in instructional programs. In W. Sailor, B. Wilcox, \& L. Brown (Eds.), Methods of instruction for severely handicapped (pp. 159-192). Baltimore: Paul H. Brooks.

Harris, V.W., \& Sherman, J.A. (1973). Effects of peer tutoring and consequences on the math performance of elementary classroom students. Journal of Applied Behavior Analysis, 6, 587-595.

Heron, T.E., Heward, W.L., Cooke, N.L., \& Hill, D.S. (1983). Evaluation of a classwide peer tutoring system: First graders teach each other sight words. Education \& Treatment of Children, 6, 137-152.

Kerr, M.M., \& Nelson, C.M. (1983). Strategies for managing behavior problems in the classroom. Columbus, $\mathrm{OH}$ : Charles E. Merrill.

Kimball, W.H., Heron, T.E., \& Weiss, A.B. (1984). New federalism and deregulation: Impact on special education. Remedial \& Special Education, 5(2), 25-31.

Kounin, J. (1970). Discipline and group management in classrooms. New York: Holt, Rinehart, \& Winston.

Leinhardt, G., Zigmond, N., \& Cooley, W.W. (1981). Reading instruction and its effects. American Educational Research Journal, 18, 343-361.

Meisgeier, C., \& Menius, L. (1980). A high intensity approach to teaching adolescent learning disabled students. In W.M. Cruickshank (Ed.). Approaches to learning (Vol. 1, pp. 97-109). Syracuse: Syracuse University Press.

Morsink, C.V. (1984). Teaching special needs students in regular classrooms. Boston: Little, Brown.

National Commission on Excellence in Education (1983). A nation at risk: The imperative for educational reform. Washington, DC: U.S. Dept. of Education.

Rippey, R.M. (1983). Evaluating teaching. Educational Psychologist, 18, 25-32.

Roehler, L.R., \& Duffy, G.G. (1984). Direct explanation of comprehension processes. In G.G. Duffy, L.R. Roehler, \& J. Mason (Eds.), Comprehension instruction: Perspectives and suggestions (pp. 265-280). New York: Longman.

Rosenshine, B. (1977). Review of teaching variables and student achievement. In G.D. Borich \& K.S. Fenton (Eds.), The appraisal of teaching: Concepts and process (pp. 114-120). Menlo Park, CA: Addison-Wesley.

Rosenshine, B. (1980). How time is spent in elementary classrooms. In C. Denham \& A. Lieberman (Eds.), Time to learn (pp. 107-126). Washington, DC: National Institute of Education.

Rosenshine, B. (1983). Teaching functions in instructional programs. Elementary School Journal, 83, 335-352.

Soar, R.S. (1973). Follow through classroom process measurement and pupil growth (1970-71). Gainesville: University of Florida, Institute for the Development of Human Resources. (ERIC Document Reproduction Service No. ED 106 297)

Stallings, J., \& Kaskowitz, D. (1974). Follow through classroom observation evaluation, 1972-73. Menlo Park, CA: Stanford Research Institute.

Stevens, R., \& Rosenshine, B. (1980). Advances in research on teaching. Exceptional Education Quarterly, 2, 1-9.

Thurlow, M.L., Ysseldyke, J.E., Graden, J., \& Algozzine, B. (1983). Instructional ecology for students in resource and regular classrooms. Teacher Education \& Special Education, 6, 248-254.

Wesson, C.L., King, R.P., \& Deno, S.L. (1984). Direct and frequent measurement of student performance: If it's good for us, why don't we do it? Learning Disability Quarterly, 7, 45-48.

Wong, B.Y.L., Wong, R., \& LeMare, L. (1982). The effects of knowledge of criterion task on comprehension and recall in normally achieving and learning disabled children. Journal of Educational Research, 76, 119-126. 


\section{ADDITIONAL REFERENCES}

Wyne, M.D., \& Stuck, G.B. (1982). Time and learning: Implications for the classroom teacher. Elementary School Journal, 83, 67-75.

Yinger, L. (1979). Routines in teacher planning. Theory into Practice, 18, 163-169.

\section{computer update}

\author{
By Barbara Thompson, Jerry Chaffin, \\ and Bill Maxwell
}

In the not too distant future we will have trouble remembering how we managed to teach without microcomputers. But currently, information on how to effectively integrate microcomputers into a classroom setting is limited. As both software developers and educators, we are often asked for assistance by teachers who will be encountering their first experience with a microcomputer in their classrooms. The questions most frequently posed by teachers in this situation are:

\section{Q: How should I introduce the computer to my students?}

A: Operating a microcomputer is an extremely easy process that requires no more than a few routine steps, which should also include how to handle diskettes. Demonstrate and post each step, and require your students to pass a proficiency test to earn the right to use the computer independently.

\footnotetext{
Barbara Thompson is a faculty member and project director of a preservice grant for the Department of Special Education, University of Kansas, Lawrence. Jerry Chaffin is a Professor of Special Education at the University of Kansas. Bill Maxwell is a programmer for Educational Information Systems, an educational software firm with which all the authors are affiliated. If you would like to have more information or have specific questions on a topic, please let us know c/o Dr. Barbara Thompson, University of Kansas, Dept. of Special Education, Room 344, Haworth Hall, Lawrence, KS 66045.
}

Q: Where should I put the computer in my classroom?

A: Create a learning center area for the computer, and arrange the necessary materials and software in a convenient, orderly manner in the center. Be sure that (a) the traffic pattern of students to and from this area is convenient and unobtrusive, and (b) the center is within your field of vision. This will facilitate establishing the computer's place in the classroom setting, and the initial distractions that the addition of a microcomputer may cause will diminish rapidly.

Q: What rules should I establish for using the computer?

A: Rules for who, when, and how students may use the computer should be developed and implemented. For example, students should observe posted schedules for use, stay the specified amount of time, use the equipment properly, and return all materials (such as diskettes, graphs, etc.) to the proper places. It is a good idea to post the rules in the computer center and to recognize and reward students for following them.

Q: How can the computer center be managed and the rules be enforced?

A: Classroom volunteers, paraprofessionals, or students can be assigned the role of computer center manager. The manager's role might include responsibilities such as:

- Checking to ensure that the computer is turned off at the end of the day.

- Being responsible for the center remaining neat and organized.

- Assisting certain students with operation or specific software programs.

- Documenting who uses the computer each day and the software each student uses.

- Recording students' performance scores obtained on the various software packages.

Depending on the functioning level of your students and the nature of available software, the manager's role will vary. In many situations this role can rotate from student to student. Without doubt, the role is a highly valued one! 
Q: To what extent should I monitor my students'use of the microcomputer?

A: Although you will not need to be with each student every time he/she uses the computer, you should observe on a routine basis. By establishing a weekly or biweekly schedule for a few minutes of observation time per student, you will ensure efficient, systematic use.

Routine observations serve several purposes. First, you will communicate to the students that you are interested in their work with the computer. Next, you will have a better idea of minor or serious problems, as well as strengths and beneficial features of the software. You will also be able to spot problems a particular student might be having that require some attention on your part. Finally, you will become more aware of the nature of the computer as an instructional tool.

Q: How can I be sure that what my students do on the computer is effectively linked to their work with paper/pencil materials and other classroom activities?

A: The computer should become an integral part of instruction in your classroom. To ensure this:

- Select software with content that is related to your students' goals and objectives.

- Clarify the relationship between the software and other materials/activities.

- Develop or select paper/pencil materials that are directly tied to the software content/ format.

- Document and evaluate student performance on software programs and related paper/pencil material, and consider their relationship.
Q: How can I make the best use of the motivational appeal of the microcomputer?

A: Because your students will almost always highly value opportunities to use the microcomputer, you might want to implement a reward system based on the computer. The following reward systems, for example, have been successful:

- More time to use educational software as a reward for improved performance on a particular software program.

- More time to use educational software as a reward for improved performance on related classroom work.

- Time with software as a reward for a wide variety of appropriate classroom behaviors.

The above answers reflect successful practices of teachers who have linked the computer and software programs to their existing classroom curriculum and activities, as well as our own observations and experiences.

\section{RESOURCES}

Thompson, B. (1983. Sept.). Integrating the microcomputer into classroom settings: Practical guidelines for teachers. (Available from DLM/Teaching Resources, P.O. Box 400, One DLM Park, Allen, TX 75002.)

Thompson, B., Chaffin, J., \& Knackendoffel, A. (1983, March). Linking educational software to traditional instructional materials and procedures in special education classroom settings. Paper presented at the CEC/National Topical Conference on the Use of Microcomputers in Special Education, Hartford, CT. 